\title{
ISSUES IN MEDICINE Slaves of the state - medical internship and community service in South Africa
}

\author{
Nicolette Erasmus
}

Owing to a chronic shortage of medical staff in South Africa, sleep-deprived medical interns and community service doctors work up to 200 hours of overtime per month under the state's commuted overtime policy. Nurses moonlight in circumvention of the Basic Conditions of Employment Act. For trainee doctors, overtime over 80 hours is unpaid, and rendered involuntarily under threat of not qualifying to practise medicine in South Africa. As forced labour, and sleep deprivation amounting to cruel and degrading treatment, it is outlawed in international law.
No other professional group in the country is subjected to such levels of exploitation and discrimination by the state. These abuses should be challenged under the Constitution. Solutions include the installation of electronic time-recording in state hospitals, cessation of unpaid overtime, limits on medical intern shifts to a maximum of 16 hours, and an investigation by the Human Rights Commission of South Africa.

S Afr Med J 2012;102(8):655-658. DOI:10.7196/SAMJ.5987
The failings of our public health care system are evident, ${ }^{1}$ but few realise just how far the government is prepared to go to prop up a severely under-resourced public health care system as hospitals and teaching institutions teeter on the brink of collapse. ${ }^{2,3}$ This article focuses on the unfair labour practices and human rights abuses perpetrated on the most vulnerable public health care employees, trainee doctors, who work inhuman amounts of unpaid overtime under the guise of training and a misguided commuted overtime policy. Off-duty state nurses are selling their rest-time back to state hospitals through third-party agencies with the full knowledge of the state, in complete disregard for statutory limits on working hours. ${ }^{4}$ A road accident case reported that a nurse employed by the Western Cape Department of Health sued for lost 'moonlighting' hours worked at Groote Schuur Hospital in her spare time via the Albrecht Nursing Agency with the permission of her employer..$^{5}$ Those opposing such abuses find themselves in such an undemocratic and combative discourse with government that the issues require investigation by the Human Rights Commission.

\section{Background}

About 2500 graduates from South Africa's eight medical schools serve a 2-year internship, and approximately 1250 (assuming that all eligible doctors report for duty ${ }^{6}$ ) serve a further year of compulsory community service in state hospitals. Only once this training is complete may they register to practise medicine in South Africa. ${ }^{7}$

At the commencement of training, interns are presented with a standard-form 2-year fixed-term contract with the provincial health department governing the hospital to which they are assigned. In the nature of standard form contracts, the terms are not negotiable, other than for a 'choice' of four overtime options listed in an annexed

Nicolette Erasmus, a qualified attorney, is reading for a PhD in Corporate Law at the School of Law, University of the Witwatersrand, Johannesburg. commuted overtime performance contract. ${ }^{8}$ The choice is illusory, as prospective medical interns are instructed by their state hospital and their representative body, JUDASA (the Junior Doctors Association of South Africa), ${ }^{9}$ that they 'will agree to category three' specifying that 13 - 20 'actual' overtime hours be rendered per week (italics added for emphasis). Only up to 80 actual overtime hours worked are paid; overtime in excess of 80 hours per month is unpaid. The corollary is that interns are assured by JUDASA that 'no intern is to work more than 80 hours of commuted overtime per month ... [which is] sufficient for training', and '[i]f a complex does not follow these rules, they run the risk of losing their accreditation as an intern complex.'?

South Africa has a chronic shortage of skilled medical staff. ${ }^{10}$ With too few doctors and nurses ${ }^{11}$ for the patient workload, they are grossly overworked. Interns rotate through training blocks of approximately 4 months each in various disciplines, during which they are routinely allocated 120 - 200 hours of overtime per month - up to four times that permitted by the Basic Conditions of Employment Act 75 of 1997 (BCEA), and more than double the number of overtime hours for which the state contracts to pay them.

\section{Forced labour in international and domestic law}

Outlawed by the international Forced Labour Convention of 1930, and ratified by South Africa in 1997, forced labour is defined as 'all work or service which is exacted from any person under the menace of any penalty and for which the said person has not offered himself voluntarily.12 Forced labour is prohibited in South African domestic law by the Bill of Rights ${ }^{13}$ (one of the most progressive in the world), the Labour Relations $\mathrm{Act}^{14}$ and the BCEA, in terms of which all employees (including domestic workers, who were only recognised as a labour force by the International Labour Organization (ILO) in 2011) enjoy the protections of limited work hours and minimum rest periods. Many jobs require extended work hours, which are permitted within the strict parameters of the BCEA, so why are the working hours of trainee doctors so excessive?

First, by some quirk of history, workers who earn more than R115 572 per annum are exempt from the working-hour protections of the BCEA..$^{15}$ The entry-level annual salary of first-year medical interns in 2010/11was R253 998, ${ }^{9}$ more than double the level below which they are entitled to working-hour restrictions. The BCEA also exempts voluntary workers 
at charitable institutions, and senior managerial employees, ${ }^{16}$ neither of which apply to medical interns as they are entry-level employees, supervised by law. ${ }^{7}$

There is a view that financial reward adequately compensates workers for adverse working conditions, possibly on the assumption that high earnings imply seniority, enough work experience to negotiate favourable contract terms, and sufficient employment alternatives if negotiated conditions do not meet expectations. None of these assumptions are true of interns, who have no alternative but to work for the state on its terms to qualify to practise medicine in South Africa. ${ }^{?}$

Secondly, the state's occupation-specific commuted overtime policy ${ }^{17}$ was formulated over the last decade via myriad bureaucratic negotiations ${ }^{18}$ to cater for the erratic working hours of qualified doctors and medical specialists. The largest proportion of public sector overtime spend is on doctors and dentists, and the state is not happy about that. ${ }^{19}$

Thirdly, the working conditions of trainee doctors in state hospitals differ materially from their contracts: call-duty rosters for first- and second-year interns allocated to trauma units in 2012 in two major teaching hospitals in Gauteng and the Western Cape reveal that they are routinely rostered for eight 24 -hour calls per month, and instructed that there must always be an intern on call, no matter how few are allocated to the department. Calls commence at $07 \mathrm{~h} 00$ and end at 07 h00 the next day, followed by ward rounds, after which interns may leave from about $09 \mathrm{~h} 00$, or continue working, depending on their workload. A 24-hour call plus a regular work day amounts to a 32-hour shift, during which an intern gets little to no sleep. Ordinary workdays start at $07 \mathrm{~h} 00$ and end around $17 \mathrm{~h} 00$, during which a 1-hour meal break is compulsory after 5 continuous hours of work. Interns seldom get one, so it, too, counts as paid overtime. ${ }^{15}$ They have one weekend off a month with a Friday treated as a weekend day, so that they effectively work 28 days out of an average 30 , plus another 8 at night. That adds up to 160 to 200 hours of overtime each month - more than double the maximum contracted for or permitted according to JUDASA, ${ }^{9}$ of which less than $50 \%$ is paid.

The state is bound by the BCEA. ${ }^{20}$ Deviations must be favourable to employees, ${ }^{15}$ yet the commuted overtime policy for doctors is less favourable, and in several respects conflicts with the BCEA. Compulsory meal breaks and minimum rest periods after 5, 10 and 12 hours of continuous work are ignored, as are night-work protocols; the commuted overtime rate for doctors is fixed at 1.3 times their ordinary hourly wage, ${ }^{9}$ considerably lower than the 2 times hourly rate for Sunday work specified in the BCEA. ${ }^{20}$ Doctors from Laroteng Hospital in Pretoria valiantly tried to challenge the policy in the Labour Court in $2007,{ }^{20}$ claiming that it should, at the very least, comply with the BCEA. Unfortunately they lost on a legal technicality. Had the merits been properly aired, the current impasse between doctors and the state on the issue might have been averted. Instead, the problem has escalated to critical proportions.

\section{Sleep deprivation in medical interns}

One research paper observed that, compared with males, female final-year medical students were less likely to want to work overtime, but that 'may well change once the financial benefits [of overtime work] become apparent." ${ }^{21}$ This argument is fallacious because financial incentives alone are insufficient to motivate and retain all levels of health practitioners in rural areas, ${ }^{22}$ and it is physically impossible for males or females to function optimally without sleep, no matter how much they are paid to do so.

The cost of chronic and acute sleep deprivation coupled with poor working conditions is exponential. Hundreds of doctors leave public ${ }^{23}$ and community service ${ }^{8}$ every year to private practice, emigration and business. ${ }^{8}$ The adverse physical effects of sleep deprivation have been extensively documented in a medical profession notorious throughout the world for its sleepless extended work hours. Lack of sleep strongly impairs human functioning, ${ }^{24}$ and leads to memory loss, attention deficit, ${ }^{25}$ negative mood changes, ${ }^{26}$ over-optimistic risk-taking, ${ }^{27}$ prolonged post-call recovery, ${ }^{28}$ road accidents, ${ }^{29}$ mistakes on duty and in surgery, adverse health conditions, and HIV needle-stick injuries: 'We live with the constant fear of contracting HIV; I have been on antiretrovirals three times. This means a month of being sick - vomiting on a daily basis. Then there is the anxiety and panic for six weeks till you do your HIV test to see that you are negative,' reported Dr Y Unterslak..$^{30}$ Sleep cycle disruption is not only physically stressful, it is a recognised hazard of routine night shift work, a form of physical abuse, ${ }^{31}$ cruel and inhuman treatment, and a torture technique.

The United Nations Convention against Torture and Other Cruel, Inhuman or Degrading Treatment or Punishment (Convention against Torture) $)^{32}$ outlaws torture internationally. South Africa ratified the Convention in 1998, as its provisions were already in our Bill of Rights, ${ }^{13}$ but, more importantly, South Africa committed to take effective measures to prevent torture, or cruel, degrading or inhuman treatment, of anyone within ${ }^{32}$ and outside ${ }^{33}$ its borders.

Torture is 'any act by which severe pain or suffering, whether physical or mental, is intentionally inflicted on a person for such purposes as ... coercing him or a third person ... for any reason based on discrimination of any kind, when such pain or suffering is inflicted by or at the instigation of or with the consent or acquiescence of a public official or other person acting in an official capacity' (italics added for emphasis). ${ }^{32}$ Cruel, inhuman or degrading treatment is anything less than torture. It includes sleep, food and drink deprivation according to the European Court of Human Rights, ${ }^{34}$ and need not be deliberate to be unlawful. The prohibition is absolute and non-derogable, meaning that the state can never justify such treatment of anyone under any circumstances. ${ }^{35}$

\section{The word 'voluntary' is key}

'Degrading treatment ... arouses in the victim a feeling of fear, anguish and inferiority ... possibly breaking his or her physical or moral resistance $^{34}$ and mitigates against sleep-deprived and inexperienced medical interns freely and voluntarily consenting to, or resisting, adverse working conditions once they work for the state.

Modern-day forced labour, slavery-like practices and human servitude are not confined to legally compromised, destitute and underprivileged women, children and migrant or trafficked workers, but are not easily distinguished from extremely poor working conditions. $^{36}$ To facilitate identification, the ILO has categorised forced labour into state-imposed and private. ${ }^{37}$ State-imposed forced labour is permitted in exceptional circumstances such as military conscription for war, public works in national emergencies, minor civic duties and regulated prison labour. Forced labour by private agencies is always unlawful, known mostly for its commercial sexual exploitation and people-trafficking. The labour conditions of trainee doctors in South Africa are state imposed. ${ }^{7,18}$

To be unlawful, forced labour must have two key elements: it must be exacted from the employee under threat of penalty (coerced), and involuntary. ${ }^{12}$

\section{Coerced}

Threats need not be physical to be coercive; psychological force is sufficient. ' $[\mathrm{P}]$ enalties can be of a financial nature, including economic penalties linked to debts, the non-payment of wages, or the 
loss of wages accompanied by threats of dismissal if workers refuse to do overtime beyond the scope of their contract or of national law. ${ }^{36}$ This situation pertains in South Africa, where medical interns and community service doctors are dependent upon the state to qualify to practise medicine. They either work the overtime, or face disciplinary action ${ }^{18}$ and the possibly of not qualifying. There can scarcely be a more coercive penalty for trainee doctors, other than perhaps imprisonment. Provincial administrators and the Health Professions Council of South Africa (HPCSA) know the practice is unconscionable. ${ }^{9,38,39}$ However, there is ample evidence that it is endemic in state hospitals. ${ }^{40}$

Government is cognisant of its coercive powers, issuing threats in the press impugning the local and international professional standing and qualifications of protesting state doctors. Advocate Boyce Mkhize, then Registrar of the HPCSA, '[r]esponding to strikers having dared the government to fire them and face them going into private practice or emigrating [during the public service strikes of 2009], "advised" that he was "obliged" to inform regulatory bodies worldwide once a complaint had been lodged against doctors. "This has a huge bearing on whether the doctor is registered in that jurisdiction to which they may want to emigrate. Furthermore the HPCSA issues a certificate of status - a prerequisite for registering in another jurisdiction. Other regulatory bodies would not knowingly register doctors with issues of misconduct against them. Once doctors are deregistered or suspended they (also) cannot enter into private practice in South Africa," ... add[ing] ominously that the doctors' failure to heed repeated HPCSA warnings not to strike could "only serve as an aggravating factor during sentencing"'." In February 2012, the Gauteng Department of Health announced that it was prosecuting nine doctors for fraudulent overtime claims, ${ }^{41}$ and, in March 2012, with rich irony, the HSPCA launched a human rights awareness campaign encouraging members of the public to lodge complaints against the professional care they receive from doctors and health professionals. ${ }^{42}$

\section{Involuntary}

To be forced, coerced labour must also be involuntary. The ILO acknowledges that workers may enter into an employment contract voluntarily at first, and thereafter find themselves in involuntary working conditions. 'Many victims enter forced labour situations initially of their own accord, albeit through fraud and deception ... They are subsequently unable to leave their work owing to legal, physical or psychological coercion. Initial consent may be considered irrelevant when deception or fraud has been used to obtain it..36 Reynolds implied this when he wrote that 'our work contracts [referring to the commuted overtime policy] are unfair and so flawed that they cannot be implemented without committing fraud ....43 Conversely, if the state induced doctors to contract with it on false pretenses, knowing, for example, that it would not, or could not, comply, then the state could be said to have acted in bad faith, and the voluntary contractual consent obtained from medical interns would thereby be negated. The remedy for qualified medical practitioners who believe they have been deceived about their work conditions is to resign and seek employment elsewhere, which far too many have done. ${ }^{44}$ Trainee doctors, on the other hand, do not have that luxury.

Evidently, there is an overlap worldwide between forced labour and slavery-like practices. State-imposed forced labour 'clearly encompass[es] situations where individuals or social groups are forced to work for others', ${ }^{36}$ whether for economic development, political education, discrimination, labour discipline, or punishment for having participated in strikes. ${ }^{45}$ The ILO has mechanisms to monitor states such as Myanmar and China that contravene the
Forced Labour Convention, and is aware of countries in Africa that use forced labour for economic development. South Africa does not appear to be one of them: 'Forced labour imposed directly by the State, while not the largest problem in terms of numbers, remains a cause for serious concern ... in Africa ... for development purposes. ${ }^{36}$ If trainee doctors and off-duty nurses are being forced to work for the state under inhumane and exploitative conditions, then perhaps South Africa should be monitored.

Government is reluctant to admit all that is wrong with its health care system. ${ }^{3,20}$ A lack of human resources, ${ }^{46}$ competition with private health care, ${ }^{11}$ and, shockingly, the dishonesty of the state's own doctors ${ }^{47}$ are blamed. It is the state's responsibility, however, as employer not to 'permit' or 'require ${ }^{15}$ forced labour to take place in its name. The medical profession should challenge the state's discriminatory commuted overtime and compulsory community service policies under the Constitution, and at the Human Rights Commission of South Africa. If it cannot make its case in South African forums, there are international ones in which it can.

\section{The solution}

No other profession in this country is subject to the level of coercion and exploitation by the state to which medical interns and community service doctors are exposed. ${ }^{48}$ The Minister of Health must act decisively against human rights abuses to regain the moral high ground.

All state hospitals should install electronic time-recording systems to monitor and measure duty hours impartially and objectively, enabling the resource gap and cost overruns in the public health sector to be managed fairly. Only then will the destructive cycle of belligerent resistance and reactionary coercion of doctors by the state end.

The state's reliance on trainee doctors to render unpaid overtime in excess of the agreed 80 hours per month must cease immediately. Extra overtime worked must be rendered voluntarily and paid, or prohibited completely to avoid young, inexperienced interns being exploited by unscrupulous administrators.

The maximum number of working hours that an intern may work without a sleep break should be limited to $16,{ }^{49}$ after considering the research on whether some sleep during a shift is better for doctors than none. ${ }^{50}$ Clean, safe, secure and uninfested facilities ${ }^{40}$ conducive to uninterrupted sleep, should be provided for staff.

The Human Rights Commission, an executive resource, should urgently investigate the human rights abuses in state health care, in particular the state's part in re-hiring off-duty state nurses through third-party agencies in circumvention of the BCEA; forced labour of medical interns and community service doctors; violations of trainee doctors' rights to security of the person and to life, particularly at night; ${ }^{51}$ and whether the sleep, food and drink deprivation of trainee doctors constitutes cruel, inhuman and/or degrading treatment.

Moral integrity, coupled with respect for every human life, without regard to social origin, is essential for the achievement of our national health care ideals. ${ }^{8,11}$ Government acknowledges that '[s]tudies have demonstrated that it is not only financial incentives that make [doctors and nurses] leave but sometimes how they are managed or mismanaged. ${ }^{52}$ The National Development Plan Vision for $2030,{ }^{53}$ and government's commitment to the ILO on decent work for all South Africans, ${ }^{54}$ aligns with these recommendations. What is left is to 'address the structural concerns, including policy and labour market failures that give rise to forced labour in the first place. ${ }^{36}$

Conflict of interest. The author comes from an extended family of nine medical practitioners and three nursing sisters, and has a personal interest in the subject matter. 


\section{References}

1. Philp R. Hospital hell. Sunday Times, 24 May 2009. http://www.netassets.co.za/article.aspx?id=1006006 (accessed 13 May 2012)

2. Adminuser. Medunsa on its last legs? Medical Chronicle, 4 April 2011. www.medicalchronicle.co.za/ medunsa-on-its-last-legs (accessed 13 May 2012).

3. Jika T. Limpopo hospitals teeter as shock report reveals state of collapse. Media24 Investigations, 17 February 2012. http://www m24i.co.za/2012/02/17/limpopo-hospitals-teeter-as-shock-report-revealsstate-of-collapse (accessed 27 April 2012).

4. October MJ. Nursing agencies in the spotlight. The nature and health system consequences of casualization. Nursing agencies and moonlighting in South Africa. December 2010. http://www. casualization. Nursing agencies and moonlighting in South Africa. December 2010. http://www.
medinurse.co.za/IndustryRelatedInfo/ANASA\%20News\%20Flash\%208\%20Nursing\%20Agencies\%20 medinurse.co.za/Industrykelatedinfo/ANASA

5. Mlalandle v Road Accident Fund (1496/2007) [2010] ZAECGHC 124. http://www.saflii.org/za/cases/ ZAECGHC/2010/124 html (accessed 3 May 2012).

6. HRH Strategy for the Health Sector: 2012/13-2016/17, 20 January 2012 V3 at para 2.2.2 p. 44. http:// www.doh.gov.za/docs/stratdocs/2012/hrhstrat.pdf (accessed 3 May 2012)

Section 61(e) Health Professions Act 56 of 1974, read with the HPCSA's Medical and Dental Professions Board training guidelines. HPCSA Newsletter for the Medical and Dental Profession Board, September/October 2007. http://www.hpcsa.co.za/downloads/press_releases/medic_dent.pd (accessed 3 May 2012)

8. Rural Health Advocacy Project (RHAP). Rural-proofing the commuted overtime policy for medical practitioners. January 2012. http://www.rhap.org.za/wp-content/uploads/2012/03/RHAP_RuDASA Rural-Proofing_the_OvertimePolicy_January-2012.pdf (accessed 25 April 2012).

9. Internship in Mzansi. A handbook of internship brought to you by JUDASA (Junior Doctors Association of South Africa), an interest group of SAMA (South African Medical Association). 29 October 2010. http://www.judasa.org (accessed 29 April 2012).

10. Mars M. 21.Telemedicine in South Africa. IDRC Archives Canada. http://web.idrc.ca/en/ev-137471201-1-DO TOPIC.html (accessed 29 April 2012).

11. Pillay R. Work satisfaction of professional nurses in South Africa: a comparative analysis of the publi and private sectors. Human Resources for Health 2009;7:15. [http://dx.doi.org/10.1186/1478-4491-7-15] 12. Article 2(1) Forced Labour Convention, 1930 (No. 29). http://www.ilo.org/ilolex/cgi-lex/convde. pl?C029 (accessed 21 June 2012)

13. Sections 9, 11, 12 and 13 of the Bill of Rights in the Constitution of South Africa, 1996

14. Section 3(c) of the Labour Relations Act 66, 1995.

15. Section 6(3) of the BCEA.

16. Section 6(1)(a) of the BCEA.

17. Inclusive Flexible Remuneration Package System (Dispensation) for Members of the Senior Management Service (SMS) on Levels 13 to 16: Annexure D to DPSA Circular 2 of 2008, para. 11 http://www.joasa.org.za/aricles/Ann\%20D\%20-\%20SMS\%20Disp\%20wef\%201\%20Se_pdf (accessed 3 May 2012).

18. Public Service Act 103 of 1994

19. Gauteng Province Media Statement. MEC for Health and Social Development Ntombi Mekgwe. 27 February 2011. http://www.healthandsocdev.gpg.gov.za/.../2011 (accessed 13 May 2012).

20. Kosheva and Others $v$ Gauteng Department of Health and Others (JR 2328/05) [2007] ZALC 65 (19 September 2007). http://www.saflii.org/za/cases/ZALC/2007/65.html (accessed 25 April 2012).
S

21. De Vries E, Irlam J, Couper I, et al. Career plans of final-year medical students in South Africa. S Af Med J 2010;100(4):227-228.

22. Ditlopo P, Blaauw D, Bidwell P, Thomas S. Analyzing the implementation of the rural allowance in hospitals in North West Province, South Africa. J Public Health Policy 2011;32(Suppl 1):S80-93. [http://dx.doi.org/10.1057/jphp.2011.28]

23. Hudson M. Where did all the doctors go? Health24, June 2011. http://www.health24.com/news/ Health_care/1-918,63541.asp (accessed 11 May 2012)

24. Pilcher JJ. Huffcutt AI. Effects of sleep deprivation on performance: A meta-analysis. Sleep 1996;19(4):318-326

25. Lockley SW, Cronin JW, Evans EE, et al. Effect of reducing interns' weekly work hours on sleep and attentional failures. N Engl J Med 2004;351(18):1829-1837. [http://dx.doi.org/10.1056/NEJMoa041404]

26. Zohar D, Tzischinsky O, Epstein R, et al. The effects of sleep loss on medical residents' emotional reactions to work events: a cognitive-energy model. Sleep 2005;28(1):47-54.

27. Venkatraman V, Huettel SA, Chuah LY, et al. Sleep deprivation biases the neural mechanism underlying economic preferences. J Neurosci 2011;31(10):3712-3718. [http://dx.doi.org/10.1523/
ing underlying economic prefer

28. Rose M, Manser T, Ware JC. Effects of call on sleep and mood in internal medicine residents. Behav Sleep Med 2008;6(2):75-88. [http://dx.doi.org/10.1080/15402000801952914]
29. Fruchtman Y, Moser AM, Perry ZH. Fatigue in medical residents - lessons to be learned. Med Lav 2011;102(5):455-463

. Post by: ingwe on 25 May 2009. www.theswitchboard.net/index.php?topic=19348.5; wap2 (accessed 28 April 2012).

31. Dyer I. Preventing the ITU syndrome or how not to torture an ITU patient! Part I. Intensive and Critical Care Nursing 1995;11(3):130-139. [http://dx.doi.org/10.1016/S0964-3397(95)80618-0]

32. UN General Assembly. Convention against Torture and Other Cruel, Inhuman or Degrading Treatment or Punishment. 10 December 1984. United Nations, Treaty Series, vol. 1465, p. 85. http:// www.unhcr.org/refworld/docid/3ae6b3a94.html (accessed 30 April 2012).

33. Rome Statute of the International Criminal Court, 17 July 1998. http://untreaty.un.org/cod/icc/index. html (accessed 21 June 2012).

34. Ireland v UK (1978) 2 EHRR 25.

35. UN Committee against Torture (CAT), General Comment No. 2: Implementation of Article 2 by States Parties. 24 January 2008, CAT/C/GC/2. http://www.unhcr.org/refworld/docid/47ac78ce2.html (accessed 30 April 2012).

36. International Labour Conference 93rd Session Report of the Director-General 'A global alliance against forced labour' Global Report under the Follow-up to the ILO Declaration on Fundamental Principles and Rights at Work (2005), para 35. www.ilo.org/wcmsp5/groups/public/@ed.../wcms_081882.pdf (accessed 2 May 2012)

37. International Trade Union Confederation 'Mini action guide ituc'. 2008. http://www.ituc-csi.org/IMG/ pdf/guide_forced_labour_EN.pdf (accessed 10 April 2012).

38. Bateman C. No quotas please, we're new South Africans! S Afr Med J 2007;97(5):322,324,326.

39. Public Service Review Report. Basic Conditions of Employment Act implementation. Public Service \& Administration. Date of Meeting: 24 May 2000, Minutes, Appendix 1. http://www.pmg.org.za/ minutes/20000523-public-service-review-report-basic-conditions-employment-act-implementation (accessed 25 April 2012).

40. Essa ZI, Jithoo V. Post-medical interns' reflections on medical internships in South African state training hospitals. MA Research Report, School of Human and Community Development, University of the Witwatersrand, Johannesburg, April 2010. http://wiredspace.wits.ac.za/handle/10539/9209 (accessed 3 May 2012)

41. Dlamini $\mathrm{N}$. Nine doctors nabbed as Health department acts on overtime system abuse, 2012/02/27 Gauteng Online Home > News. http://www.gautengonline.gov.za/News/Pages/ NinedoctorsnabbedasHealthdepartmentactsonovertimesystemabuse.aspx (accessed 11 May 2012).

2. Media Statement. HPCSA embarks on health and human rights awareness campaign.19 March 2012. http://www.hpcsa.co.za (accessed 11 May 2012).

43. Reynolds L. Overtime contracts and salaries: a personal view. Critical Health Perspectives 2005; No. 2. http://www.phmovement.org/files/CHP_2005_No2___Overtime_contracts__salaries.pdf (accessed 29 April 2012).

44. Yeni A. South Africa: Doctors still getting short end of the stick. Health-e (Cape Town). 2 July 2010. http://www.health-e.org.za/news/article.php?uid=20032851 (accessed 14 May 2012).

45. Article 1. Abolition of Forced Labour Convention, 1957 (No. 105). http://www.ilo.org/ilolex/cgi-lex/ convde.pl? C105 (accessed 21 June 2012).

6. Thom A. Bara crisis as newborns die.10.02.2012 health-e. http://www.health-e.org.za/news/article. php?uid=20033414 (accessed 13 May 2012)

47. Adminuser. DoH urged to abolish RWOPS policy. Medical Chronicle, News, 20 July 2011. http://www. medicalchronicle.co.za/doh-urged-to-abolish-rwops-policy/ (accessed 25 April 2012).

48. cf. Department of Tourism, Environment and Conservation 'Policy on Working Hours and Overtime Human Resources Management? 1 December 2008. www.northern-cape.gov.za/index (accessed 3 May 2012).

49. Iglehart JK. Revisiting duty-hour limits - IOM Recommendations for Patient Safety and Resident Education. N Engl J Med 2008;359(25):2633-2635. [http://dx.doi.org/10.1056/NEJMp0808736]

50. Nasca TJ, Day SH, Amis ES Jr, et al. The new recommendations on duty hours from the ACGME Task Force. N Engl J Med 2010;363(2):e3. Epub 2010 Jun 23. [http://dx.doi.org/10.1056/NEJMsb1005800]

51. R178 Night Work Recommendation.1990. www.ilo.org/ilolex/cgi-lex/convde.pl?R178 (accessed 11 May 2012)

52. Child K. Health minister promises more doctors and nurses. Mail \& Guardian, 11 October 2011. http://mg.co.za/article/2011-10-11-health-minister-promises-more-doctors-and-nurses/ (accessed 25 April 2012).

53. Chapter 10. Promoting Health National Planning Commission. National Development Plan. 11 November 2011. www.npconline.co.za (accessed 29 April 2012).

54. ILO Online reports from Johannesburg, South Africa. Empowering South Africans with decent work. 7 October 2011. http://www.ilo.org/global/meetings-and-events/regional-meetings/africa/arm-12 WCMS_164682/lang--en/index.htm (accessed 11 May 2012).

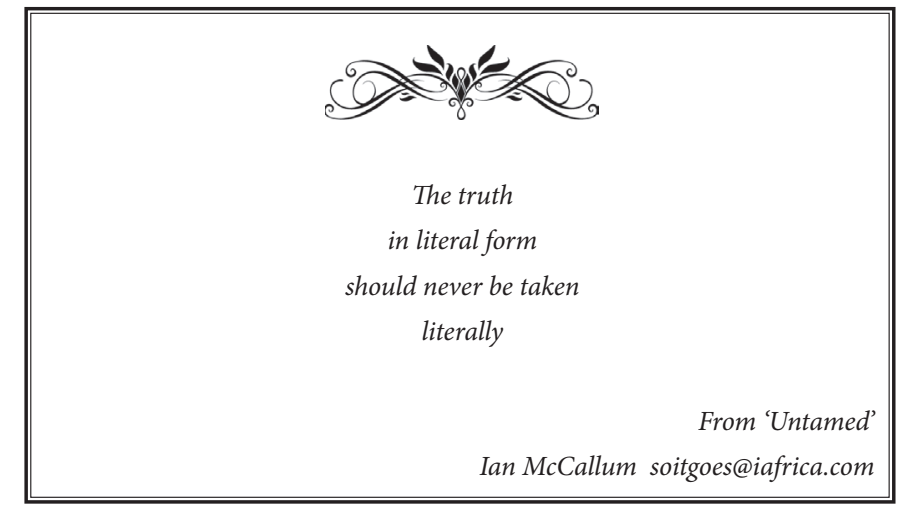

